\author{
M.Yu. Ishmuratova*, S.S. Tyrzhanova \\ Karagandy University of the name of academician E.A. Buketov, Kazakhstan \\ (*E-mail: margarita.ishmur@mail.ru)
}

\title{
Study of peculiarities of morphology and germination of seeds of Scabiosa ochroleuca from the Central Kazakhstan
}

\begin{abstract}
The study of the biology and morphology of seed germination of medicinal plants is an important aspect of species introduction. This article investigated the features of the biology of germination and seed germination of a perspective medicinal plant Scabiosa ochroleuca depending on various factors. It is determined that seeds of some geographical origin differ in size and weight, the morphology of seedlings, which is explained by the difference in soil and climatic conditions. The best values of germination $(90.5 \%)$ and germination energy $(80.3 \%)$ of seeds were recorded in large samples collected in the Buiratau mountains, the minimum - in small seeds collected in the Karkaraly mountains (germination $14.0 \%$, germination energy $8.5 \%$ ). The maximum morphological parameters of seedlings, such as the length of the root, the length of the hypocotyl, the length and width of the cotyledon leaf, are revealed in seeds from the Karkaraly mountains; the minimum - from the vicinity of the village Karagaily. This aspect indicates the need to select seeds for introduction from certain habitats and to separate them before sowing. Stages of germination of seed material of this medicinal plant are defined, including the following: swelling of seeds, tilting, appearance of root, appearance and bending of hypocotyl, removal of cotyledon leaves, and deployment of cotyledon leaves. Dynamics of seeds germination during storage (from freshly harvested seeds up to 3 years) was determined, positive influence of stratification during 3 months was revealed to increase seed germination and germination energy. According to the results of the studies, it was determined that the seeds of Scabiosa ochroleuca are characterized by the lack of drainage during wetting, the terrestrial type of germination, shallow physiological rest, by the type of germination are assigned to the group of seeds with accelerated germination.
\end{abstract}

Keywords: herb, Scabiosa ochroleuca, Central Kazakhstan, seed germination, energy of germination, morphology, natural flora, storage, size of seeds.

\section{Introduction}

Plants from different habitats form different potentials of productivity, morphological structures and variability according to some characteristics. So, depending on the growing conditions, plants can develop organs of various sizes, the intensity of physiological processes changes, which is reflected in the size and performance of seeds [1-3]. In favorable conditions of growing, seeds are formed large, full-fledged and with a well-developed embryo and a supply of nutrients.

Identification of the influence of factors on the development and germination indicators of seeds is important for issues of plant introduction, as well as factors that can increase the germination of seed material.

Introduction into the culture of medicinal plants has an important practical interest for the sustainable production of vegetative raw materials. About 6500 species of plants grow in Kazakhstan, along with cultivated taxa. Of these compositions, $85 \%$ belong to herbaceous plants, 730 species are endemic, of which 175 species grow in steppe regions, 250 species of desert and semi-desert zones, 600 endangered species, more than 1000 species are used in official and folk medicine [4, 5]. One perspective species is Scabiosa ochroleuca L. (Dipsacaceae family), the aboveground part of which is used in folk medicine for stomach diseases, female and ocular diseases, for the excretion of warts, wound healing, in scabies, skin rash, hemorrhoids, calluses, snake bites, anti-opaque Extracts from this plant have pronounced antimicrobial and antioxidant activity $[9,10]$.

Extracts from this plant have pronounced antimicrobial and antioxidant activity [9, 10].

In Kazakhstan there is information about natural resources of this species [11], however, no introduction work was carried out.

The purpose of this work is to study the features of the morphological structure of Scabiosa ochroleuca seeds of various geographical origin; and determination of their biology of germination. 


\section{Objects and methodology}

The object of the study was the seed material of Scabiosa ochroleuca, collected in Karkaraly Mountains and surrounding of village Karagaily (Karkaraly district, Karaganda region), Buiratau Mountains (Osakarov district, Karaganda region). Research was carried out in 2018-2020 on the basis of the Research Center of Biotechnology and Eco-Monitoring of E.A. Buketov Karaganda State University.

The seed material was separated by size and weight (small, medium and large), the length, width and weight 1000 pieces were measured, and after germinated. To assess the germination of seeds, they were germinated 50 pieces in three repetitions on humidified 2-layer filter paper in Petri dishes at a temperature $+24{ }^{\circ} \mathrm{C}$ in the climate chamber. Seeds after harvesting were study in fresh as well as after stratification from 1 to 3 months. Stratification was performed in the refrigerator. To determine viability depending on period of storage, seed germination and germination energy for 3 years were evaluated.

The study of germination and germination energy of seeds was carried out according to the methodological instructions of M.S. Zorina and S.P. Kabanov [12].

Morphology of seeds and seedlings was examined on a Levenguk USB-microscope at an increase of 40-80 times [13]. For seedlings, the following parameters were evaluated: total height of plants, length of the hypocotyls, length and width of the cotyledon leaves; length of the root system. The weight of the seedlings according to the test versions was estimated by weighing on the analytical weights in 10 -fold repetition on dry weight [14].

The study of the biology of seed germination was carried out taking into account the recommendations of K.E. Ovcharov, E.G. Kizilova [15], M.K. Firsova [16], P. Wellington [17].

Statistical processing of the results was carried out according to the method of N.L. Udolskaya [18] using the Microsoft Excel 2010 software package.

\section{Results and discussion}

The fruit Scabiosa ochroleuca is an achene with a serrated-wavy film crown, light brown, singleseeded, with an oily endosperm, pericarpium 8-sided deep-notched, cone-shaped. The length is $1.5-2 \mathrm{~cm}$; the width is $0.4-0.6 \mathrm{~cm}$. The shape of the seed is kidney-shaped, oval or rounded (Fig. 1).

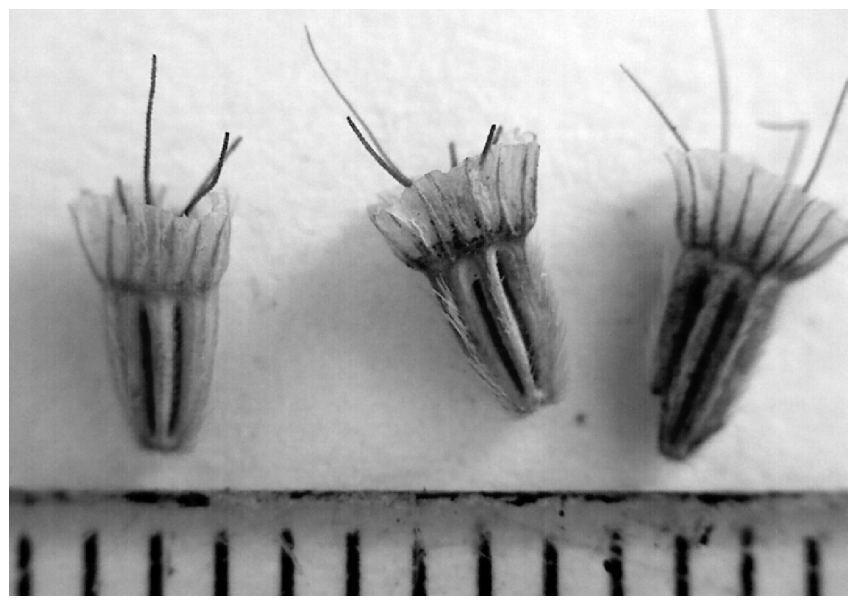

Figure 1. Internal view of seed materials of Scabiosa ochroleuca

The biology of seed germination of Scabiosa ochroleuca has been studied. During soaking, the seeds swelled, increasing in size by 1.2-1.3 times; no sliming was observed. The absence of dehumidification indicates plant growth under mesophyte conditions [19].

Seed deposition in laboratory conditions occurred on 2-3 days. At the same time, pericarpium was opened and the germ root was the first to appear from the achene. Its length was 6-8 mm; diameter $0.4-0.5$ $\mathrm{mm}$. Root hairs are weakly visible on the end of the root. After (on day 4-5), a milk-white hypocotyl appeared, the rest was still hidden in the seed. On day 6-8, the hypocotyl was drawn, forming a bend (Fig. 2), then straightened, carrying the cotyledons outside. Hypocotyl is white, elastic, $10-12 \mathrm{~mm}$ length and $0.5-0.6$ $\mathrm{mm}$ in diameter. Cotyledon leaves came to the surface folded, after which they opened. 
The plate of the cotyledon leaf was narrow-lanceolate, 6-8 $\mathrm{mm}$ long, 4-5 mm wide, color was light green, the surface is smooth, the apex is weakly notched. The height of the seedling by this period was $1.8-2 \mathrm{~cm}$, the length of the root was $2.4-2.6 \mathrm{~cm}$; root hairs became noticeable.

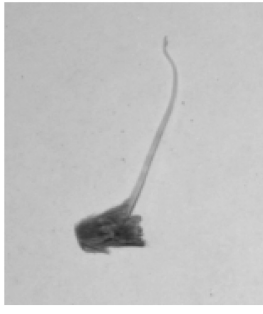

A

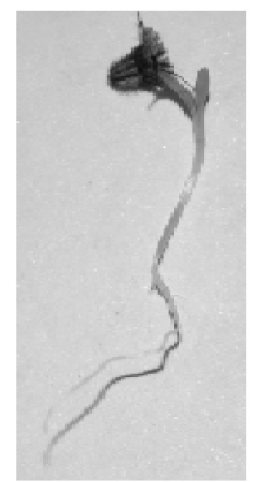

D

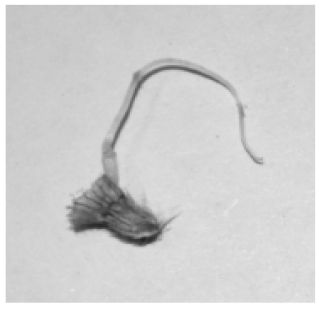

$B$

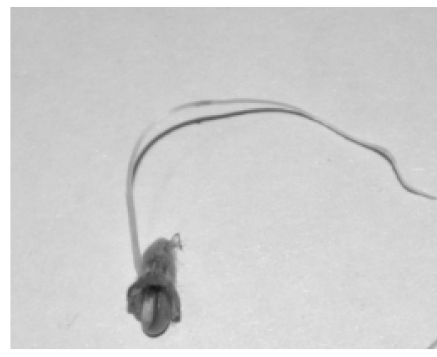

C

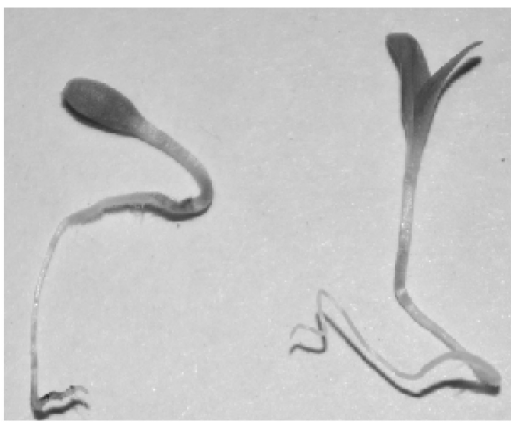

E

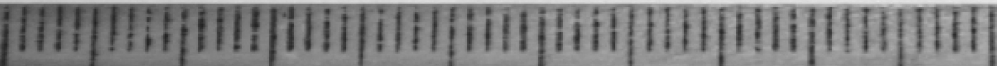

$A$ - the appearance of the germ root; $B$ - the appearance and bend of the hypocotyl;

$C$ - the appearance of cotyledon leaves; $D$ - the output of folded cotyledon leaves;

$E$ - a prophet with a pair of cotyledon leaves

Figure 2. Biology of germination of seeds of Scabiosa ochroleuca

Thus, the seeds of Scabiosa ochroleuca are characterized by above-ground type of germination, characterized by a shallow physiological rest. By the type of germination [20,21] are assigned to the group of seeds with accelerated germination.

Morphological analysis showed that the seed material of different geographical origins differed in size and weight (Table 1).

$\mathrm{Tab} l \mathrm{e} 1$

Morphological parameters of seeds of Scabiosa ochroleuca depending from origin

\begin{tabular}{|l|c|c|c|c|}
\hline \multicolumn{1}{|c|}{ Origin of seeds } & $\begin{array}{c}\text { Average length of seed, } \\
\mathrm{cm}\end{array}$ & $\begin{array}{c}\text { Average width of } \\
\text { seed, cm }\end{array}$ & Weight 1000 pieces, g & $\begin{array}{c}\text { Number of seeds } \\
\text { per one florescence, } \\
\text { pieces }\end{array}$ \\
\hline Buiratau Mountains & $2.6 \pm 0.2$ & $1.5 \pm 0.06$ & $0.16 \pm 0.01$ & $296 \pm 12$ \\
\hline $\begin{array}{l}\text { Surrounding of village } \\
\text { Karagaily }\end{array}$ & $2.7 \pm 0.1$ & $1.8 \pm 0.04$ & $0.21 \pm 0.01$ & $315 \pm 25$ \\
\hline Karkaraly Mountains & $3.4 \pm 0.4$ & $1.7 \pm 0.05$ & $0.32 \pm 0.02$ & $345 \pm 31$ \\
\hline
\end{tabular}

As can be seen from the given data, the maximum length had seeds from the Karkaraly Mountains $3.4 \mathrm{~cm}$; by thickness - the maximum values were obtained for seeds from the surrounding of village Karagaily $-1.8 \mathrm{~cm}$; and the maximum weight of seeds is recorded for seeds from the Karkaraly Mountains.

However, the size and weight of the seeds do not reflect quality indicators, so we determined germination and energy of germination. It was determined that the best indicators were noted Scabiosa ochroleuca 
seeds collected in the Buiratau Mountains (Table 2), the second position in germination was taken by seeds from the surrounding of village Karagaily; seeds from Karkaraly Mountains were on the third position.

T a b l e 2

Indicators of seed germination and germination energy of Scabiosa ochroleuca, depending on the places of origin

\begin{tabular}{|l|c|c|}
\hline \multicolumn{1}{|c|}{ Origin of seeds } & Seed germination, $\%$ & Energy of germination, $\%$ \\
\hline Buiratau Mountains & $64.5 \pm 2.6$ & $50.4 \pm 0.8$ \\
\hline Surrounding of village Karagaily & $61.0 \pm 2.8$ & $52.9 \pm 1.8$ \\
\hline Karkaraly Mountains & $50.1 \pm 2.1$ & $41.0 \pm 0.9$ \\
\hline
\end{tabular}

It is worth noting that the size and weight of the seeds do not correlate with the germination data. It turns out that seeds from the Buiratau Mountains with a minimum weight of seeds gave maximum germination indicators, while the largest and heaviest seeds turned out to be the least germinating.

Thus, the seed material of Scabiosa ochroleuca differs in size and weight depending on the place of growth. So, the largest seeds are formed in Karkaraly Mountains, the smallest - in Buiratau Mountains. This aspect can be explained by the fact that in Karkaraly Mountains more mesophytic conditions are observed (more precipitation), which leads to a good development of plant morphology. In Buiratau Mountains, the conditions are more xerophytic, so the size of the seeds is lower. However, data on seed germination and energy of germination turned out to be higher in Buiratau Mountains, which is probably due to the fact that the formation of seeds depends on solar activity, which is higher at this point.

In the second stage of research, the effect of seed sizes from different collection points on germination indicators was studied. All samples from collection points were divided into 3 fractions (large, medium and small), for which germination peculiarities were separately estimated. The results showed that large seeds had maximum values for parameters of germination (Table 3 ).

Table 3

Germination and energy of germination of seeds of Scabiosa ochroleuca depending from size

\begin{tabular}{|l|c|c|c|}
\hline \multicolumn{1}{|c|}{ Origin of seeds } & Fraction of seeds & Seed germination, \% & Energy of germination, \% \\
\hline \multirow{3}{*}{ Buiratau Mountains } & Large & $90.5 \pm 3.5$ & $80.3 \pm 3.9$ \\
& Medium & $62.4 \pm 2.8$ & $51.2 \pm 2.5$ \\
& Small & $26.4 \pm 0.5$ & $20.1 \pm 0.7$ \\
\hline \multirow{2}{*}{ Surrounding of village } & Large & $60.2 \pm 3.0$ & $50.1 \pm 1.8$ \\
Karagaily & Medium & $61.4 \pm 3.4$ & $52.0 \pm 1.6$ \\
& Small & $28.5 \pm 0.8$ & $12.4 \pm 0.6$ \\
\hline \multirow{3}{*}{ Karkaraly Mountains } & Large & $46.2 \pm 1.1$ & $38.0 \pm 0.8$ \\
& Medium & $45.5 \pm 1.0$ & $40.1 \pm 1.1$ \\
& Small & $14.0 \pm 0.5$ & $8.5 \pm 0.3$ \\
\hline
\end{tabular}

Maximum indicators of germination were recorded for large seeds from Buiratau Mountains - $90.5 \%$ with energy of germination $80.3 \%$; minimum indicators - for small seeds from Karkaraly Mountains $14.0 \%$ and $8.5 \%$ respectively. It has been determined that for Scabiosa ochroleuca seeds, in order to increase the efficiency of storage of seeds in culture, it is advisable to collect the initial material at certain points and to separate the seeds in favor of larger ones.

We analyzed the state of Scabiosa ochroleuca seedlings, obtained from seeds of different size and origin. There is a positive relationship between seed size and seedling size (Table 4).

At all collection points, it was found that the most made seedlings are obtained from large seeds, while smaller seedlings are obtained from small seeds. The obtained results once again confirm that the use of large seeds allows obtaining larger and more developed seedlings. It is worth noting that the maximum difference between seedlings from seeds of different sizes is observed in Buiratau Mountains, the minimum in Karkaraly Mountains.

Analysis of the germination of Scabiosa ochroleuca, depending on period of storage, showed that the seed material gradually loses its germination. So, freshly harvested seeds $58.8 \%$, after 3 months of storage - slightly increased to $62.4 \%$. This aspect is explained by seed ripening [14, 15, 19, 20]. After 
6 months, germination decreased to $55.2 \%$, a year later - to $40.3 \%$, after 1.5 years - to $36.8 \%$, after 3 years - to $18.2 \%$ (Fig. 3 ).

Ta ble 4

Morphological parameters of Scabiosa ochroleuca seedlings depending on the size of seeds and origin

\begin{tabular}{|l|c|c|c|c|c|}
\hline \multicolumn{1}{|c|}{ Origin of seeds } & Fraction of seeds & $\begin{array}{c}\text { Length of root, } \\
\mathrm{cm}\end{array}$ & $\begin{array}{c}\text { Length of hypo- } \\
\text { cotyls, mm }\end{array}$ & $\begin{array}{c}\text { Length of coty- } \\
\text { ledon leaves, mm }\end{array}$ & $\begin{array}{c}\text { Width of cotyledon } \\
\text { leaves, mm }\end{array}$ \\
\hline Buiratau Mountains & Large & $5.4 \pm 0.2$ & $5.5 \pm 0.4$ & $7.2 \pm 0.5$ & $3.5 \pm 0.2$ \\
& Medium & $3.1 \pm 0.1$ & $2.8 \pm 0.1$ & $5.6 \pm 0.4$ & $3.0 \pm 0.2$ \\
& Small & $2.5 \pm 0.05$ & $2.4 \pm 0.1$ & $4.9 \pm 0.4$ & $2.2 \pm 0.1$ \\
\hline Surrounding of village & Large & $5.0 \pm 0.4$ & $4.8 \pm 0.4$ & $6.5 \pm 0.4$ & $3.8 \pm 0.4$ \\
& Medium & $4.4 \pm 0.2$ & $4.6 \pm 0.3$ & $5.5 \pm 0.3$ & $3.5 \pm 0.2$ \\
& Small & $4.2 \pm 0.2$ & $4.5 \pm 0.2$ & $1.5 \pm 0.3$ & $1.0 \pm 0.05$ \\
\hline Karkaraly & Large & $6.2 \pm 0.3$ & $5.5 \pm 0.2$ & $5.6 \pm 0.2$ & $4.0 \pm 0.1$ \\
& Medium & $6.4 \pm 0.4$ & $4.7 \pm 0.2$ & $6.0 \pm 0.3$ & $3.8 \pm 0.1$ \\
& Small & $3.1 \pm 0.1$ & $2.6 \pm 0.1$ & $4.6 \pm 0.2$ & $3.0 \pm 0.1$ \\
\hline
\end{tabular}

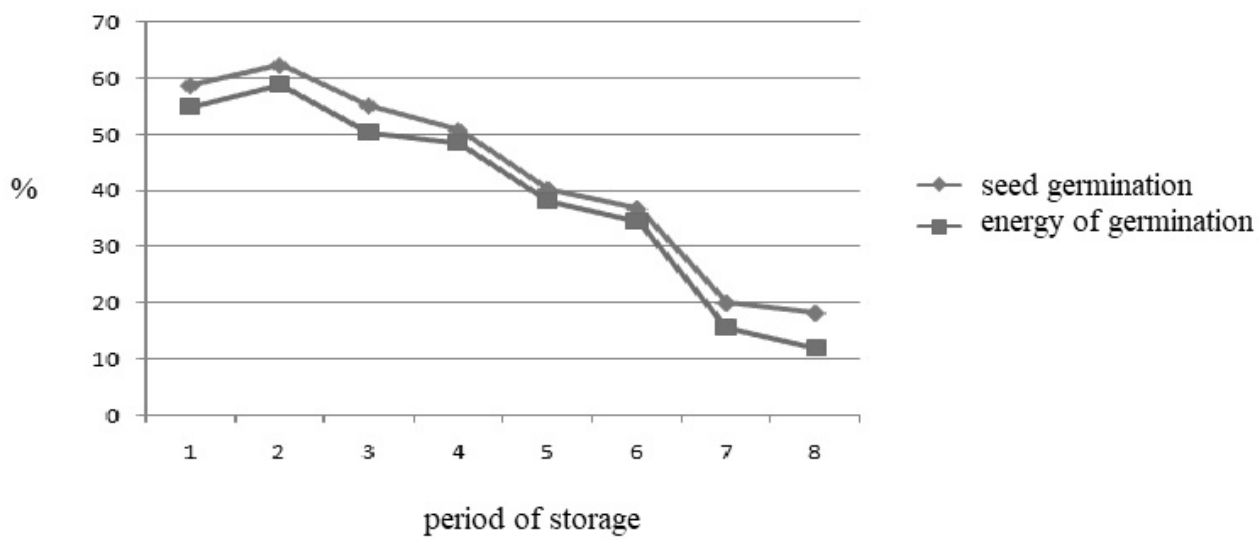

1 - freshly picked; $2-3$ months; $3-6$ months; $4-9$ months; $5-12$ months; $6-18$ months; 7 - 24 months; $8-36$ months

Figure 3. Germination and energy of germination of seeds of Scabiosa ochroleuca during storage

Thus, over the course of 3 years, we have seen a significant decrease in germination rates, which requires the development of methods for increasing it. We tested cold stratification.

Stratification was carried out in a freezer with seeds from Buiratau Mountains after 1 year of storage for 1 to 3 months. The initial germination was $40.3 \%$, and the germination energy was $37.5 \%$. During stratification, there is an increase in germination and germination energy indicators (Table 5).

Table 5

Germination and energy of germination of seeds of Scabiosa ochroleuca after cold stratification

\begin{tabular}{|l|c|c|c|c|}
\hline \multicolumn{1}{|c|}{ Methods of treatment } & Seed germination, \% & $\begin{array}{c}\text { Exceeding control, } \\
\%\end{array}$ & $\begin{array}{c}\text { Energy of germina- } \\
\text { tion, \% }\end{array}$ & Exceeding control, \% \\
\hline Control & $40.3 \pm 0.8$ & - & $37.5 \pm 0.6$ & - \\
\hline Stratification, 1 month & $55.2 \pm 2.0$ & +4.9 & $47.4 \pm 0.9$ & +9.9 \\
\hline Stratification, 2 months & $58.8 \pm 2.8$ & +18.5 & $56.3 \pm 2.2$ & +18.8 \\
\hline Stratification, 3 months & $64.2 \pm 3.4$ & +23.9 & $58.7 \pm 2.6$ & +21.2 \\
\hline
\end{tabular}

It is worth noting that after the 1st month of storage, the germination of Scabiosa ochroleuca seeds increased by $4.9 \%$ and germination energy by $9.9 \%$; after 2 months of storage by 18.5 and $18.8 \%$, respectively; and after 3 months of storage by 23.9 and $21.2 \%$, respectively. According to the results of the experiment, the best results were obtained against the background of a 3-month stratification period. 


\section{Conclusion}

Thus, it was determined that the seeds of Scabiosa ochroleuca have different morphological indicators, which is explained by the difference in environmental conditions of plant growth. The largest and heaviest seeds are noted in plants growing in Karkaraly Mountains with the most favorable soil and climatic conditions; the smallest are for individuals from Buiratau Mountains with the most arid conditions.

It is noted that seeds of Scabiosa ochroleuca of different size and weight vary in terms of germination and size of seedlings. The best values of germination (90.5\%) and germination energy $(80.3 \%)$ of seeds were recorded in large samples collected in Buiratau Mountains; the minimum — in small seeds collected in Karkaraly Mountains (germination $14.0 \%$, germination energy $8.5 \%$ ). There is a more significant correlation between seed size and germination. The maximum morphological parameters of seedlings, such as the length of the root, the length of the hypocotyl, the length and width of cotyledon leaves, are revealed in seeds from Karkaraly Mountains; the minimum - from surrounding of the village Karagaily. This aspect indicates the need to select seeds for introduction from certain habitats and to separate them before sowing.

Stages of germination of seed material of this medicinal plant are defined, including the following: swelling of seeds, tilting, appearance of root, appearance and bending of hypocotyl, removal of cotyledon leaves, deployment of cotyledon leaves. The type of germination is above ground.

During storage, there is a gradual decrease in germination and germination energy from $58.8 \%$ for freshly harvested seeds to $18.2 \%$ after 3 years of storage. It was determined that physical methods of treating seeds positively affect the increase in germination and germination energy of Scabiosa ochroleuca. The best results were obtained with cold stratification for 3 months (germination $64.2 \%$, germination energy $58.7 \%$ ). Seeds are characterized by a shallow physiological rest, which is easily overcome by stratification, by the type of germination - to a group of seeds with accelerated germination.

Obtained results can be used for formation of seed bank of medicinal plants and introduction of Scabiosa into culture.

The research was carried out within the framework of internal grant of E.A. Karaganda State University № 218-B-19 «Cryopreservation of vegetative and animal biological materials for development algorithm of storage of viability and creation of bank of frozen samples».

\section{References}

1 Хатнянский В.И. Влияние крупности семян на их посевные и урожайные свойства / В.И. Хатнянский, В.В. Волгин, Л.Е. Пивень // Науч.-техн. бюл. Всерос. НИИ масличных культур. - 2005. - Вып. 1(132). - С. $42-48$.

2 Абеуов С.К. Семеноведение: учеб.-метод. пос. / С.К. Абеуов, А.К. Алтынбаева. - Павлодар: Кереку, 2016. - 85 с.

3 Созинов А.В. Семеноводство и сертификация семян: метод. указ. для лаб.-практ. занятий / А.В. Созинов. - Лесниково: КГСХА, 2014. - $56 \mathrm{c}$.

4 Грудзинская Л.М. Аннотированный список лекарственных растений Казахстана: справоч. / Л.М. Грудзинская, Н.Г. Гемеджиева, Н.В. Нелина, Ж.Ж. Каржаубекова. — Алматы: Ин-т ботаники и фитоинтродукции, 2014. — 200 с.

5 Байтенов М.С. Флора Казахстана. — Т. 1: Иллюстрированный определитель семейств и родов / М.С. Байтенов. Алматы: Ғылым, 1999. - 185 с.

6 Растительные ресурсы России. Дикорастущие цветковые растения, их компонентный состав и биологическая активность. - Т. 5. - СПб., М.: КМК, 2012. - 295 с.

7 Жунусова M.А. Фармацевтическая разработка лекарственных средств из растительного сырья Scabiosa ochroleuca L. и Scabiosa isetensis L.: дис. ... PhD. 6D074800 — «Технология фармацевтического производства» / М.А. Жунусова. — Караганда, 2019. - $173 \mathrm{c}$.

8 Pinto D. Scabiosa genus: A rich source of Bioactive Metabolites / D. Pinto, N. Rahmouni, N. Beghidja, A.M. Silva // Medicines. — 2018. — Vol. 5, No. 4. — P. 110-120. — URL: https://doi.org/10.3390/medicines5040110.

9 Zhunusova M.A. Constituent composition and biological activity of $\mathrm{CO}_{2}$-extracts of Scabiosa isetensis and S.ochroleuca / M.A. Zhunusova, E.M. Suleimen, Z.B. Iskakova, M.Yu. Ishmuratova, R.M. Abdullabekova // Chemistry of Natural Compounds. 2017. — Vol. 53, No. 2. — P. 775-777. — URL: https://doi.org/10.1007/s10600-017-2118-9.

10 Жунусова М.А. Антимикробная и противогрибковая активность $\mathrm{CO}_{2}$-экстрактов растений семейства Dipsacaceae / М.А. Жунусова, А.К. Кударинова, С.Б. Ахметова, Р.М. Абдуллабекова, С.К. Кабиева, М.К. Ибраев // Фармация Казахстана. - 2017. - № 3(189). — C. 23-25.

11 Ishmuratova M.Yu. Study of spreading and plant resources of herbs Scabiosa ochroleuca L. and Scabiosa isetensis L. on the territory of Karaganda region / M.Yu. Ishmuratova, M.A. Zhunusova, S.S. Tyrzhanova, M.M. Salint'eva // Bulletin of the Karaganda University. Series Biology. Medicine. Geography. — 2020. — No. 1(97). — P. 47-53. — URL: https://doi.org/10.31489/ 2020BMG1/47-53.

12 Зорина М.С. Определение семенной продуктивности и качества семян интродуцентов / М.С. Зорина, С.П. Кабанов // Методики интродукционных исследований в Казахстане. - Алма-Ата: Наука, 1986. - С. 75-85. 
13 Мальцева М.В. Пособие по определению посевных качеств семян лекарственных растений / М.В. Мальцева. — М., 1950. - $56 \mathrm{c}$.

14 Методические указания по семеноведению интродуцентов. - М.: Наука, 1980. — 64 c.

15 Овчаров К.Е. Разнокачественность семян и продуктивность растений / К.Е. Овчаров, Е.Г. Кизилов. - М.: Колос, 1966. - $160 \mathrm{c}$.

16 Фирсова М.К. Методы определения качества семян / М.К. Фирсова. — М.: Наука, 1959. — 224 с.

17 Веллингтон П. Методика оценки проростков семян / П. Веллингтон. — М.: Колос, 1973. — 175 с.

18 Удольская Н.Л. Методика биометрических расчетов / Н.Л. Удольская. - Алма-Ата: Наука, 1976. — 45 с.

19 Николаева М.Г. Биология семян / М.Г. Николаева, И.В. Лянгузова, Л.М. Позднова. - СПб., 1999. — 232 с

20 Николаева М.Г. Справочник по проращиванию покоящихся семян / М.Г. Николаева, М.В. Разумова, В.Н. Гладкова. - Л.: Наука, 1985. - 347 с.

21 Андросова Д.Н. Биология прорастания семян некоторых видов сем. Asteraceae Dumort. / Д.Н. Андросова, Н.С. Данилова // Изв. Самар. науч. центра РАН. - 2017. — Т. 19, № 2. - С. 104-109.

\title{
М.Ю. Ишмуратова, С.С. Тыржанова
}

\section{Орталық Қазақстанда өсетін Scabiosa ochroleuca тұқымының өнімділігі мен морфологиясының ерекшеліктерін зерттеу}

\begin{abstract}
Дәрілік өсімдіктердің тұқымдарының өсуінің биологиясы мен морфологиясын зерттеу түрлерді интродукциялық енгізудің маңызды аспектісі болып табылады. Мақалада әртүрлі факторларға байланысты перспективті дәрілік өсімдік бозсары қотырот тұқымының өсу биологиясы және тұқымның өнгіштігінің ерекшеліктері зерттелген. Әртүрлі географиялық ортадан алынған тұқымдардың мөлшері мен салмағы және өскіндер морфологиясы бойынша ерекшеленетіні анықталды, бұл өз кезегінде топырақ пен климаттық жағдайлардың айырмашылығымен түсіндіріледі. Тұқымның өнгіштігінің (90,5 \%) және өну энергиясының (80,3 \%) ең жақсы көрсеткіштері Бұйратау тауларында жиналған ірі сынамаларда, төмен көрсеткіштер Қарқаралы тауларында жиналған ұсақ тұқымдарда (өнгіштік деңгейі 14,0\%, өну энергиясы 8,8\%) болды. Тұқымдардың мөлшері мен олардың өнгіштігі арасында анағұрлым маңызды корреляциялық байланыс анықталды. Тамырдың, гипокотилдің және жарнақты жапырағының ұзындығы мен ені сияқты өскіндердің морфологиялық параметрлерінің максималды мәні керісінше Қарқаралы тауларындағы тұқымдарда, төмен мәндері Қарағайлы кенті маңайынан жиналған тұқымдарда кездесті. Бұл аспект интродукция үшін белгілі бір мекен ету ортасынан тұқым таңдап, оларды егу алдында бөлу кажеттілігін көрсетеді. Дәрілік өсімдіктің тұқымдық материалының өну кезеңдері анықталды, оның ішінде: тұқымдардың бөртуі, олардың бекінуі, тамырдың, гипокотилдің пайда болуы және бүгілуі, жарнақты жапырақтарының шығарылуы және жазылуы. Сақтау кезінде тұқымның өну динамикасы (жаңадан жиналған тұқымнан бастап 3 жылға дейін), 3 айдың ішінде тұқымның өнгіштігі мен өну энергиясын арттыруға арналған стратификацияның оң әсері анықталған. Зерттеу нәтижелері бойынша Scabiosa ochroleuca тұқымдары ылғал болған кезде шырыштанбайтындығымен, өнгіштігінің жер үсті түрімен, терең емес физиологиялық тыныштық күйімен сипатталып, өну түріне сәйкес жеделдетілген өнгіштігі бар тұқымдар тобына жататындығы анықталды.
\end{abstract}

Кілт сөздер: дәрілік өсімдік, Scabiosa ochroleuca, Орталық Қазақстан, тұқымның өнімділігі, өну энергиясы, морфология, табиғи флора, сақтау, тұқым мөлшері.

\section{М.Ю. Ишмуратова, С.С. Тыржанова}

\section{Изучение особенностей морфологии и всхожести семян Scabiosa ochroleuca из Центрального Казахстана}

\begin{abstract}
Изучение биологии и морфологии прорастания семян лекарственных растений является важным аспектом интродукции видов. В статье исследованы особенности биологии прорастания и семенной всхожести перспективного лекарственного растения скабиозы бледно-желтой в зависимости от различных факторов. Определено, что семена разного географического происхождения отличаются по размеру и весу, морфологии проростков, что объясняется разницей почвенных и климатических условий. Лучшие значения всхожести $(90,5 \%)$ и энергии прорастания $(80,3 \%)$ семян зафиксированы у крупных образцов, собранных в горах Буйратау, минимальные - у мелких семян, собранных в горах Каркаралы (всхожесть - 14,0 \%, энергия прорастания - 8,5 \%). Максимальные морфологические параметры проростков, такие как длина корня, длина гипокотиля, длина и ширина семядольного листа, наоборот, выявлены у семян из гор Каркаралы, минимальные - из окрестностей пос. Карагайлы. Данный аспект свидетельствует о необходимости отбора семян для интродукции из определенных
\end{abstract}


мест обитания и их сепарации перед посевом. Определены этапы прорастания семенного материала лекарственного растения, включающие следующие: набухание семян, наклевывание, появление корня, появление и изгиб гипокотиля, вынос семядольных листьев, развертывание семядольных листьев. Определена динамика всхожести семян в процессе хранения (от свежесобранных семян до 3-х лет), выявлено положительное влияние стратификации в течение 3-х месяцев для повышения всхожести и энергии прорастания. По итогам исследований определено, что семена Scabiosa ochroleuca характеризуются отсутствием ослизнения при намокании, наземным типом прорастания, неглубоким физиологическим покоем, по типу прорастания отнесены к группе семян с ускоренным прорастанием.

Ключевые слова: лекарственное растение, Scabiosa ochroleuca, Центральный Казахстан, семенная всхожесть, энергия прорастания, морфология, природная флора, хранение, размер семян.

\section{References}

1 Hatnyanskij, V.I., Volgin, V.V., \& Piven, L.E. (2005). Vliianie krupnosti semian na ikh posevnye i urozhainye svoistva [Effect of seed size on sowing and crop properties]. Nauchno-tekhnicheskii biulleten Vserossiiskoho NII maslichnykh kultur - Scientific-technical Bulletin of All-Russian Institute of oil-bearing crops, 1(132), 42-48 [in Russian].

2 Abeuov, S.K., \& Altynbaeva, A.K. (2016). Semenovedenie [Seed breading]. Pavlodar: Kereku [in Russian].

3 Sozinov, A.V. (2014). Semenovodstvo i sertifikatsiia semian [Seed production and certification of seeds]. Lesnikovo: KGSCA [in Russian].

4 Grudzinskaya, L.M., Gemedzhieva, N.G., Nelina, N.V., \& Karzhaubekova, Zh.Zh. (2014). Annotirovannyi spisok lekarstvennykh rastenii Kazakhstana: Spravochnik [The annotated list of medicinal plants of Kazkahstan. Reference book]. Almaty: Institute of Botany and Phyto-Introduction [in Russian].

5 Baitenov, M.S. (1999). Flora Kazakhstana. T. 1: Illiustrirovannyi opredelitel semeistv i rodov [Flora of Kazakhstan. Vol. 1: Illustrated determinant of families and genera]. Almaty: Hylym [in Russian].

6 Rastitelnye resursy Rossii. Dikorastushchie tsvetkovye rasteniia, ikh komponentnyi sostav i biolohicheskaia aktivnost [Plant resources of Russia. Wild flowering plants, their component composition and biological activity]. (2012). (Vol. 5). Saint PetersburgMoscow: KMK [in Russian].

7 Zhunusova, M.A. (2019). Farmatsevticheskaia razrabotka lekarstvennykh sredstv iz rastitelnoho syria Scabiosa ochroleuca L. i Scabiosa isetensis L. [Pharmaceutical development of herbal drugs Scabiosa ochroleuca L. and Scabiosa isetensis L.]. PhD thesis on specialty 6D074800 - Technology of pharm industry. Karaganda [in Russian].

8 Pinto, D., Rahmouni, N., Beghidja, N., \& Silva, A.M. (2018). Scabiosa genus: A rich source of Bioactive Metabolites. Medicines, 5(4), 110-120. URL: https://doi.org/10.3390/medicines5040110.

9 Zhunusova, M.A., Suleimen, E.M., Iskakova, Z.B., Ishmuratova, M.Yu. \& Abdullabekova R.M. (2017). Constituent composition and biological activity of $\mathrm{CO}_{2}$-extracts of Scabiosa isetensis and S.ochroleuca. Chemistry of Natural Compounds, 53(2), 775777. URL: https://doi.org/10.1007/s10600-017-2118-9.

10 Zhunusova, M.A., Kudarinova, A.K., Ahmetova, S.B., Abdullabekova, R.M., Kabieva, S.K., \& Ibraev, M.K. (2017). Antimikrobnaia i protivohribkovaia aktivnost $\mathrm{CO}_{2}$-ekstraktov rastenii semeistva Dipsacaceae [Antimicrobial and antifungal activity of $\mathrm{CO}_{2}$-extracts of plants of family Dipsacaceae]. Farmatsiia Kazakhstana - Pharmacia of Kazakhstan, 3(189), 23-25 [in Russian].

11 Ishmuratova, M.Yu., Zhunusova, M.A., Tyrzhanova, S.S., \& Salinteva, M.M. (2020). Study of spreading and plant resources of herbs Scabiosa ochroleuca L. and Scabiosa isetensis L. on the territory of Karaganda region. Bulletin of the Karaganda University. Series Biology. Medicine. Geography, 1(97), 47-53. URL: https://doi.org/10.31489/2020BMG1/47-53.

12 Zorina, M.S., \& Kabanov, S.P. (1986). Opredelenie semennoi produktivnosti i kachestva semian introdutsentov [Determination of seed productivity and quality of seeds of introduced plants]. Metodiki introduktsionnykh issledovanii v Kazakhstane - Methodology of introduction study in Kazakhstan. Alma-Ata: Nauka [in Russian].

13 Maltseva, M.V. (1950). Posobie po opredeleniiu posevnykh kachestv semian lekarstvennykh rastenii [Manual for determining the sowing qualities of medicinal plant seeds]. Moscow [in Russian].

14 Metodicheskie ukazaniia po semenovedeniiu introdutsentov [Mannual for seed breading of introduced plants]. (1980). Moscow: Nauka [in Russian].

15 Ovcharov, K.E., \& Kizilov, E.G. (1966). Raznokachestvennost semian i produktivnost rastenii [Different quality of seeds and plant productivity]. Moscow: Kolos [in Russian].

16 Firsova, M.K. (1959). Metody opredeleniia kachestva semian [Methods of determination of seed quality]. Moscow: Nauka [in Rusian].

17 Wellington, P. (1973). Metodika otsenki prorostkov semian [Procedure for assessment of seed seedlings]. Moscow: Kolos [in Russian].

18 Udolskaya, N.L. (1976). Metodika biometricheskikh raschetov [Biometric Calculation Methodology]. Alma-Ata: Nauka [in Russian]. sian].

19 Nikolaeva, M.G., Lyanguzova, I.V., \& Pozdnova, L.M. (1999). Biolohiia semian [Seed biology]. Saint-Petersburg [in Rus-

20 Nikolaeva, M.G., Razumova, M.V. \& Gladkova, V.N. (1985). Spravochnik po prorashchivaniiu pokoiashchikhsia semian [Germination Guide for Resting Seeds]. Leningrad: Nauka [in Russian].

21 Androsova, D.N. \& Danilova N.S. (2017). Biolohiia prorastaniia semian nekotorykh vidov semeistva Asteraceae Dumort. [Biology of germination of seeds of some species from fam. Asteraceae Dumort]. Izvestiia Samarskoho nauchnoho tsentra RAN Bulletin of Samara scientific center of RAS, 19(2), 104-109 [in Russian]. 